Print ISSN: 2288-4637 / Online ISSN 2288-4645

doi:10.13106/jafeb.2020.vol7.no11.469

\title{
Validating the Entrepreneurial Intention Model on the University Students in Saudi Arabia
}

\author{
Najmul HODA ${ }^{1}$, Naim AHMAD ${ }^{2}$, Mobin AHMAD ${ }^{3}$, Abdullah KINSARA ${ }^{4}$, Afnan T. MUSHTAQ \\ Mohammad HAKEEM ${ }^{6}$, Mwafaq AL-HAKAMI ${ }^{7}$
}

Received: August 01, 2020 Revised: September 20, 2020 Accepted: October 05, 2020

\begin{abstract}
The main objective of this paper is to examine the applicability of Linan and Chen's entrepreneurial intention model (EIM) in predicting the entrepreneurial intention. EIM is an adaptation of the Theory of Planned Behavior that focuses on entrepreneurial intention and hypothesizing slightly different patterns of relationship with regards to subjective norms. The model also includes human capital and demographic factors. Snowball sampling method was used to collect data using the entrepreneurial intention questionnaire (EIQ) through several social media platforms. The survey indicates that the overall entrepreneurial intention of Saudi students is high $($ mean $=5.41)$. Eight out of the seventeen hypothesized relationships were found to be significant. Among the demographic variables, gender-personal attitude was significant whereas self employment experience and years of business education were found to be significantly related with perceived behavioral control. The statistical analysis using partial least square structural equation modelling validated the model. All the three antecedents of entrepreneurial intention were significantly related with entrepreneurial intention. The results of this study will help policy makers to get deep understanding into the phenomenon of entrepreneurship among Saudi university students and thereby develop a conducive environment. This study also validates the entrepreneurial intention model in a different cultural context.
\end{abstract}

Keywords: Entrepreneurial Intention, Theory of Planned Behavior, Entrepreneurial Intention Model, Entrepreneurial Intention Questionnaire, Saudi Arabia

JEL Classification Code: I23, L26, M13

${ }^{1}$ First Author and Corresponding Author. Assistant Professor, Department of Business Administration, College of Business, Umm Al-Qura University, Kingdom of Saudi Arabia [Postal Address: Al-Abidiyah, Makkah, 21955, Kingdom of Saudi Arabia]

Email: nnhoda@uqu.edu.sa

${ }^{2}$ Lecturer, Department of Information Systems, College of Computer Science, King Khalid University, Kingdom of Saudi Arabia. Email: nagqadir@kku.edu.sa

${ }^{3}$ Professor, Department of Mathematics, College of Science, Jazan University, Kingdom of Saudi Arabia. Email: msyed@jazanu.edu.sa ${ }^{4}$ Department of Business Administration, College of Business, Umm Al-Qura University, Kingdom of Saudi Arabia.

Email: aboody591@gmail.com

${ }^{5}$ Smart Dreams Tech, Umm Al-Qura University, Kingdom of Saudi Arabia. Email: Afnan-tahir@outlook.sa

${ }^{6}$ Saudi Telecom Company, Riyadh, Kingdom of Saudi Arabia. Email:m.z.7akeem@gmail.com

${ }^{7}$ Department of Business Administration, College of Business, Umm Al-Qura University, Kingdom of Saudi Arabia.

Email: Mwafaq.Alhakami@gmail.com

(c) Copyright: The Author(s)

This is an Open Access article distributed under the terms of the Creative Commons Attribution Non-Commercial License (https://creativecommons.org/licenses/by-nc/4.0/) which permits unrestricted non-commercial use, distribution, and reproduction in any medium, provided the original work is properly cited.

\section{Introduction}

Entrepreneurship is gaining significant attention across the world because it contributes to the better utilization of resources and overcomes the problem of unemployment. Increasing number of start-ups and nascent ventures are being treated as a benchmark for economic growth. In light of these, new researches are focusing on the factors that determine entrepreneurial behavior in individuals. Intention has been previously been found to be a good predictor of behavior (Rahman, et al. 2020; Choukir, et al. 2019; Kautonen, van Gelderen, \& Fink, 2015; Bui, et al. 2020; Bosma, et al. 2008). The youth, especially students, have been the most important subject of entrepreneurship research. The reason is that students make their career choices and a supportive environment may stimulate them to opt for entrepreneurship. Liñán et al. (2011a) point out an important reason why testing intention models are important. They opine that a good understanding of the underlying antecedents can be used to develop an educational environment that facilitates entrepreneurship. 
In Saudi Arabia, the government has identified entrepreneurship as a major facilitator in achieving their transformation plan, famously known as the Saudi Vision 2030. Diversification from the oil-based economy, inducing economic transformation and containing unemployment may all be significantly supported by entrepreneurship. Universities have started introducing courses on entrepreneurship and establishing centers for entrepreneurship and innovation. The government has established a Small and Medium Enterprise Authority (SMEA) called Monsha'at in order to provide necessary support to entrepreneurs. Majority of the banks are offering customized products for small and medium enterprises. There is also emphasis placed on women entrepreneurship. All these steps have resulted in growth of entrepreneurship and an increase in start-ups in the last few years.

The number of studies dealing with entrepreneurial intention (EI) of Saudi students are few (Ali, 2016; Almobaireek, 2012; Choukir et al., 2019). Therefore, this study tries to address this gap by studying the entrepreneurship intention of Saudi university students using the EIM and tested earlier in several countries (Lee-Ross, 2017; Liñán \& Chen, 2006; Liñán, et al. 2013; Liñán, et al. 2011a). The paper structure is described as follows. Section 2 discusses the literature review. The research methodology is presented in Section 3. Results and findings are presented in Section 4 and the conclusion is presented in Section 5.

\section{Literature Review}

The literature review suggests that research on EI has been receiving more attention in the recent past (Hongdiyanto, et al. 2020; Vuong, et al. 2020; Amanamah, et al. 2018; Choukir et al., 2019; Ferri, et al. 2018; Jahani, et al. 2018; Miao, 2016; Nabi, et al. 2017; Păunescu, et al. 2018). Fewer studies were found to be based in Arab countries (Aloulou, 2016; Iqbal, et al. 2012; Naushad \& Malik, 2018; Almobaireek, 2012).

\subsection{Theoretical Background}

EI has been explained as a mental process of planning business ideas (Gupta \& Bhawe, 2007; Boyd \& Vozikis, 1994). There is no consensus on the definition of EI in literature. However, the definitions that deem appropriate in context of this research are that EI is "the intention to start a new business" (De Pillis \& Reardon, 2007) and it is a "a state of mind that direct attention, experience and action toward a business concept, set the form and direction of organizations at their inception" (Bird, 1988).

There are various theoretical models that have been identified in the literature that explain the factors influencing entrepreneurial intention. Theory of Planned Behavior (Ajzen, 1991) mainly focused on the psychological traits to explain intentions. It has been used to explain EI as well (Audet, 2004; Kolvereid \& Isaksen, 2012; Krueger et al., 2000; Engle et al., 2010). Luthje and Franke's model (Lüthje \& Franke, 2003) included both personality traits and perceived environmental factors to explain the EIs of individuals. Entrepreneur Event Model (Licht \& Siegel, 2009) is another model that explains intention. Its distinction is that it considers perception of the desirability and feasibility to be affecting the intention. Social networking theory (Granovetter, 1973) tries to explain entrepreneurship in terms of social networks. It argues that entrepreneurship can thrive when people have access to business networks (Neergaard, et al. 2005). In a way, it proposes that the degree of social networking also affects the EI.

\subsection{Entrepreneurial Intention Model}

Among the various models of EI, TPB has been used the most, in its original form (Ferri et al., 2018; Krueger et al., 2000; Kolvereid \& Isaksen, 2012; Ariff, Bidin, Sharif, \& Ahmad, 2010; Autio, Keeley, Klofsten, \& Ulfstedt, 1997; Kautonen et al., 2015) or with adaptations (Muhammad, Aliyu, \& Ahmed, 2015; Naushad, 2018; Liñán et al., 2013; Liñán, Rodríguez-Cohard, \& Rueda-Cantuche, 2011b). Liñán et al., (2013) categorized studies based on TPB into four different strands namely, "the effect of core TPB elements on entrepreneurial intention; the effect of human and social capital on the TPB elements and EI; the effect of knowledge and awareness of the entrepreneurial environment on TPB elements and EI; cross-cultural research". The TPB was adapted to develop the EIM that narrowed down the focus of the original model on entrepreneurial intention (Al-Jubari, Hassan, \& Liñán, 2019; Francisco Liñán \& Chen, 2006; Francisco Liñán et al., 2013; Francisco Liñán, RodríguezCohard, \& Rueda-Cantuche, 2005). In EIM, the antecedents of EI are called, "personal preference or attraction towards entrepreneurship; the perceived social norms regarding that career option; and, thirdly, the perceived entrepreneurial selfefficacy". In order to measure the entrepreneurial intention, an instrument called the Entrepreneurship Intention Questionnaire was developed and tested (Liñán, 2005; Liñán $\&$ Chen, 2006). The demographic factors or human capital are also included in the EIM.

\subsection{Human Capital and Demographic Variables}

Variables such as "age, gender, skills, personalities, education, knowledge and prior experience" have been termed as human capital (Fitzsimmons \& Douglas, 2011; Ferri, et al. 2018). Some studies included all the variables while some considered only a few of them or added new variables. Liñán \& Chen (2006) included age, gender, role model, selfemployment experience and work experience in the construct named human capital. Work experience and self-employment 
experience were found to be related in other studies (Miralles, Giones, \& Riverola, 2016; Soria-Barreto, et al. 2017; Israr \& Saleem, 2018). The constituents of human capital have been studied independently or in combination. Gender has been investigated in many studies and most of them concluded that male are more inclined toward entrepreneurship (Ferri et al., 2018; Hongdiyanto et al., 2020). Entrepreneurship education, institutional environment and curriculum have been found to be influencing EI (Lu \& Wang, 2018; NGUYEN, 2020; do Paço, et al. 2011; Liñán et al., 2011a; Tran, et al. 2018). Role models have also been found to be positively influencing EI (Amouri, et al. 2016).

\subsection{Hypotheses}

The Entrepreneurship Intention Model (Figure 1) as described in the above section forms the theoretical framework of this study. Age has not been considered in this study as it was not found to be significant in other studies. The hypotheses to be tested are mentioned below.

H1: Personal Attitude (PA) positively influences entrepreneurial intention

H2: Perceived behavioral control (PBC) positively influences entrepreneurial intention

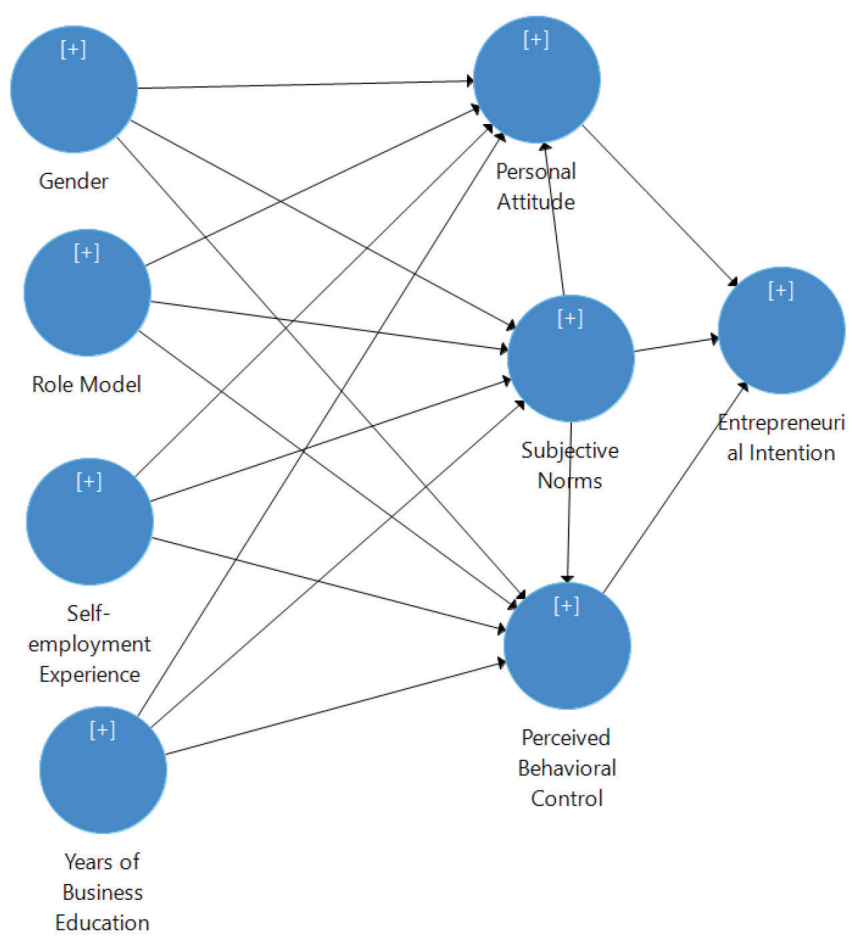

Figure 1: Entrepreneurship Intention Model (Adapted from Liñán \& Chen, 2006)
H3: Subjective norm (SN) positively influences entrepreneurial intention

H4: Gender positively influences the antecedents of EI

H5: Role Model positively influences the antecedents of EI

H6: Work Experience positively influences the antecedents of EI

H7: Business Education positively influences the antecedents of EI

\section{Research Methods and Materials}

The research was conducted using primary data collected mainly through Google Form. The link was shared using social media and also personal contacts of the students. The population included only the students pursuing business programs in Saudi universities. A total of 270 responses received were from different universities of Saudi Arabia. Out of 270 only 250 responses were valid. The data was prepared in SPSS 20.0 and the structural equation modeling was done using SmartPLS (v.3.2.8).

\subsection{Descriptive Statistics}

The descriptive statistics have been summarized in Table 1. The descriptive statistics have been summarized in Table 2. The gender distribution of the sample shows that $65.6 \%$ of the respondents were male students whereas $34.4 \%$ were female. The maximum concentration of respondents is in the age groups of 19-21 and 22-24 respectively. Majority of the respondents did not have previous self-employment experience $(72 \%)$, whereas about half of all the respondents knew an entrepreneur to be their role model. Most of the students had received 2-3 years of business education and almost all were pursuing undergraduate programs.

Table 1: Descriptive statistics

\begin{tabular}{|l|l|c|c|}
\hline \multicolumn{2}{|c|}{} & $\begin{array}{c}\text { Frequency } \\
\text { (N = 250) }\end{array}$ & Percentage \\
\hline \multirow{2}{*}{ Gender } & Male & 158 & $63.2 \%$ \\
\cline { 2 - 4 } & Female & 92 & $36.8 \%$ \\
\hline \multirow{2}{*}{$\begin{array}{l}\text { Self- } \\
\text { employment }\end{array}$} & Yes & 70 & $28.0 \%$ \\
\cline { 2 - 4 } & No & 180 & $72.0 \%$ \\
\hline \multirow{2}{*}{ Role model } & Yes & 139 & $55.6 \%$ \\
\cline { 2 - 4 } & No & 111 & $44.4 \%$ \\
\hline \multirow{2}{*}{$\begin{array}{l}\text { Years of } \\
\text { business } \\
\text { education }\end{array}$} & $1-2$ & 168 & $67.2 \%$ \\
\cline { 2 - 4 } & $3-4$ & 79 & $31.6 \%$ \\
\cline { 2 - 4 } & $\begin{array}{l}5 \& \\
\text { above }\end{array}$ & 3 & $1.2 \%$ \\
\hline
\end{tabular}


Table 2: Reliability and Validity

\begin{tabular}{|l|c|c|c|}
\hline $\begin{array}{l}\text { Construct/ } \\
\text { Indicators }\end{array}$ & $\begin{array}{c}\text { Outer } \\
\text { Loadings }\end{array}$ & $\begin{array}{c}\text { Composite } \\
\text { Reliability }\end{array}$ & AVE \\
\hline $\begin{array}{l}\text { Entrepreneurial } \\
\text { Intention }\end{array}$ & & 0.923 & 0.667 \\
\hline EI1 & 0.753 & & \\
\hline EI2 & 0.807 & & \\
\hline EI3 & 0.863 & & \\
\hline El4 & 0.869 & & \\
\hline EI5 & 0.782 & & \\
\hline EI6 & 0.820 & & \\
\hline Personal Attitude & & 0.862 & 0.565 \\
\hline PA1 & 0.451 & & \\
\hline PA2 & 0.815 & & \\
\hline PA3 & 0.743 & & \\
\hline PA4 & 0.850 & & \\
\hline PA5 & 0.826 & & \\
\hline $\begin{array}{l}\text { Perceived } \\
\text { Behavioral Control }\end{array}$ & & 0.892 & 0.582 \\
\hline PBC1 & 0.671 & & \\
\hline PBC2 & 0.824 & & \\
\hline PBC3 & 0.851 & & \\
\hline PBC4 & 0.790 & & \\
\hline PBC5 & 0.756 & & \\
\hline PBC6 & 0.663 & & \\
\hline Subjective Norms & & 0.851 & 0.658 \\
\hline SN1 & 0.878 & & \\
\hline SN2 & & & \\
\hline SN3 & & & \\
\hline
\end{tabular}

\subsection{Measures of EIQ}

Entrepreneurial Intention Questionnaire (EIQ) was used for this study. The EIQ was first developed by Linan (Liñán, 2005). It was used and tested in other studies (Liñán \& Chen, 2009; Liñán, et al. 2011). The EIQ measures EI on four subscales: "attitudes toward entrepreneurship, subjective norms, perceived behavioral control, and entrepreneurial intention" consisting of five, three, six and six items respectively. All items were measured on a 7-point Likert scale. The mean score for 6 items measuring entrepreneurial intention was found to be 5.39 which indicates an above average rating. Other studies conducted in the USA and China showed weaker intention for venture creation with mean scores of less than 3.0 on a 5-point Likert scale (Lee, et al. 2006). Another research in Turkey examining actual motivation of small and medium firms found mean score values of less than 3.4 (Benzing, et al. 2009).

\section{Results and Discussion}

The model shown in Figure 1 was entered into the SmartPLS (v.3.2.8) software. PLS algorithm was run with the default basic settings. The analysis was done in two phases. Firstly the measurement model is assessed for reliability and validity (Table 2). And in the next stage, the structural model is assessed. The results of the model had shown that the 16 indicators loadings above 0.7. However, indicators having loading between .4 and .7 may also be retained based on their relationship with the construct (Garson, 2016). In this study only PA1 has values of 0.451 and $\mathrm{SN} 1, \mathrm{PBC} 1$ and $\mathrm{PBC} 2$ have values above 0.65 . Moreover, bootstrapping routine shows all of the factor loading to be significant. Other reliability and validity measures such as composite reliability and AVE are also shown in Table 3 . The constructs are having good internal consistency reliability, composite reliability score above 0.85 (Hair, Ringle, \& Sarstedt, 2011). The Average Variance Extracted (AVE) for all the constructs is above 0.5, therefore it exhibits adequate convergent validity (Hair et al., 2011).

As for the discriminant validity, the matrix shown in Table 3 consists of AVE values, the diagonal vales are higher than that of the values below it (Fornell-Larcker criterion), therefore the discriminant validity is adequate (Hair et al., 2011).

In Table 4, all the paths having $\mathrm{p}>0.05$ are significant and shown with asterisk. Some paths are showing negative values meaning having negative influence such as the subjective norm is negatively influencing entrepreneurial intention. Eight out of the seventeen paths were found to be significant, whereas the rest were not found to be significant. Still, the relationships indicate weak to moderate degree of strength. Among the demographic variables, gender was found to have significant relationship with personal attitude only. Self employment experience (SEE) and years of business education (YBE) both were found to have significant relationship with perceived behavioral control (PBC).

Once the reliability and validity of measurement model is established, analysis may proceed to next stage of structural model. In this stage coefficient of determination (R-square) for endogenous variables, path coefficients and statistical significance through bootstrapping are analyzed. In Figure 2, values inside the circle are for $\mathrm{R}$ - square and can be described as moderate to weak (Hair et al., 2011). 
Table 3: Discriminant validity

\begin{tabular}{|c|c|c|c|c|c|c|c|c|}
\hline & El & G & PBC & PA & RM & SEE & SN & YBE \\
\hline Entrepreneurial Intention (EI) & 0.817 & & & & & & & \\
\hline Gender (G) & -0.002 & 1.000 & & & & & & \\
\hline Perceived Behavioral Control (PBC) & 0.428 & -0.058 & 0.763 & & & & & \\
\hline Personal Attitude (PA) & 0.541 & -0.136 & 0.242 & 0.751 & & & & \\
\hline Role Model (RM) & 0.207 & 0.036 & 0.204 & 0.012 & 1.000 & & & \\
\hline Self-employment Experience (SEE) & 0.114 & 0.088 & 0.214 & 0.058 & 0.037 & 1.000 & & \\
\hline Subjective Norms (SN) & 0.006 & -0.070 & 0.111 & 0.216 & -0.088 & 0.018 & 0.811 & \\
\hline Years of Business Education (YBE) & 0.043 & -0.233 & 0.231 & 0.073 & 0.146 & -0.011 & 0.026 & 1.000 \\
\hline
\end{tabular}

Table 4: Structural Equation Modelling results

\begin{tabular}{|l|c|c|c|c|c|}
\hline & Original Sample & Sample Mean & Standard Deviation & T Statistics & P Values \\
\hline Gender $\rightarrow$ PBC & -0.029 & -0.030 & 0.063 & 0.456 & 0.649 \\
\hline Gender $\rightarrow$ PA & -0.120 & -0.120 & 0.057 & 2.087 & $0.037^{*}$ \\
\hline Gender $\rightarrow$ SN & -0.063 & -0.069 & 0.081 & 0.779 & 0.436 \\
\hline $\mathrm{PBC} \rightarrow$ EI & 0.324 & 0.326 & 0.057 & 5.679 & $0.000^{*}$ \\
\hline $\mathrm{PA} \rightarrow$ EI & 0.492 & 0.494 & 0.059 & 8.374 & $0.000^{*}$ \\
\hline $\mathrm{RM} \rightarrow \mathrm{PBC}$ & 0.179 & 0.182 & 0.064 & 2.778 & 0.006 \\
\hline $\mathrm{RM} \rightarrow \mathrm{PA}$ & 0.027 & 0.026 & 0.066 & 0.408 & 0.684 \\
\hline $\mathrm{RM} \rightarrow \mathrm{SN}$ & -0.090 & -0.096 & 0.076 & 1.185 & 0.237 \\
\hline $\mathrm{SEE} \rightarrow \mathrm{PBC}$ & 0.210 & 0.211 & 0.057 & 3.712 & $0.000^{*}$ \\
\hline $\mathrm{SEE} \rightarrow \mathrm{PA}$ & 0.064 & 0.065 & 0.058 & 1.119 & 0.264 \\
\hline $\mathrm{SEE} \rightarrow \mathrm{SN}$ & 0.027 & 0.020 & 0.068 & 0.401 & 0.688 \\
\hline $\mathrm{SN} \rightarrow \mathrm{EI}$ & -0.136 & -0.131 & 0.059 & 2.304 & $0.022^{*}$ \\
\hline $\mathrm{SN} \rightarrow \mathrm{PBC}$ & 0.116 & 0.111 & 0.073 & 1.591 & 0.112 \\
\hline $\mathrm{SN} \rightarrow \mathrm{PA}$ & 0.208 & 0.213 & 0.094 & 2.216 & $0.027^{*}$ \\
\hline $\mathrm{YBE} \rightarrow \mathrm{PBC}$ & 0.197 & 0.196 & 0.063 & 3.109 & $0.002^{*}$ \\
\hline $\mathrm{YBE} \rightarrow \mathrm{PA}$ & 0.036 & 0.038 & 0.060 & 0.607 & 0.544 \\
\hline $\mathrm{YBE} \rightarrow \mathrm{SN}$ & 0.025 & 0.028 & 0.072 & 0.343 & 0.731 \\
\hline
\end{tabular}

\section{Conclusions}

The results largely validated the predictive power of the EIM in the context of Saudi university students. This is consistent with a growing body of empirical evidence from a variety of cultural and institutional contexts, such as Spain (Miralles et al., 2016), UK and Spain (Liñán et al., 2013), Portugal (do Paço et al., 2011), Australia (Lee-Ross, 2017). Out of the three components of the EIM, perceived behavioral control shows relatively higher impact on entrepreneurial intentions. Subjective Norms and Personal Attitude too exhibit positive relationships with EI. All the three antecedents of EI namely PA, PBC and SN were found to have significant relationships with EI. An interesting finding in this study is about SN. SN has been showing conflicting results in the previous studies, mainly insignificant relationship with EI (Krueger et al., 2000). In this study, we found that $\mathrm{SN}$ also affects PA which is in line with results of other studies (Liñán et al., 2011). 


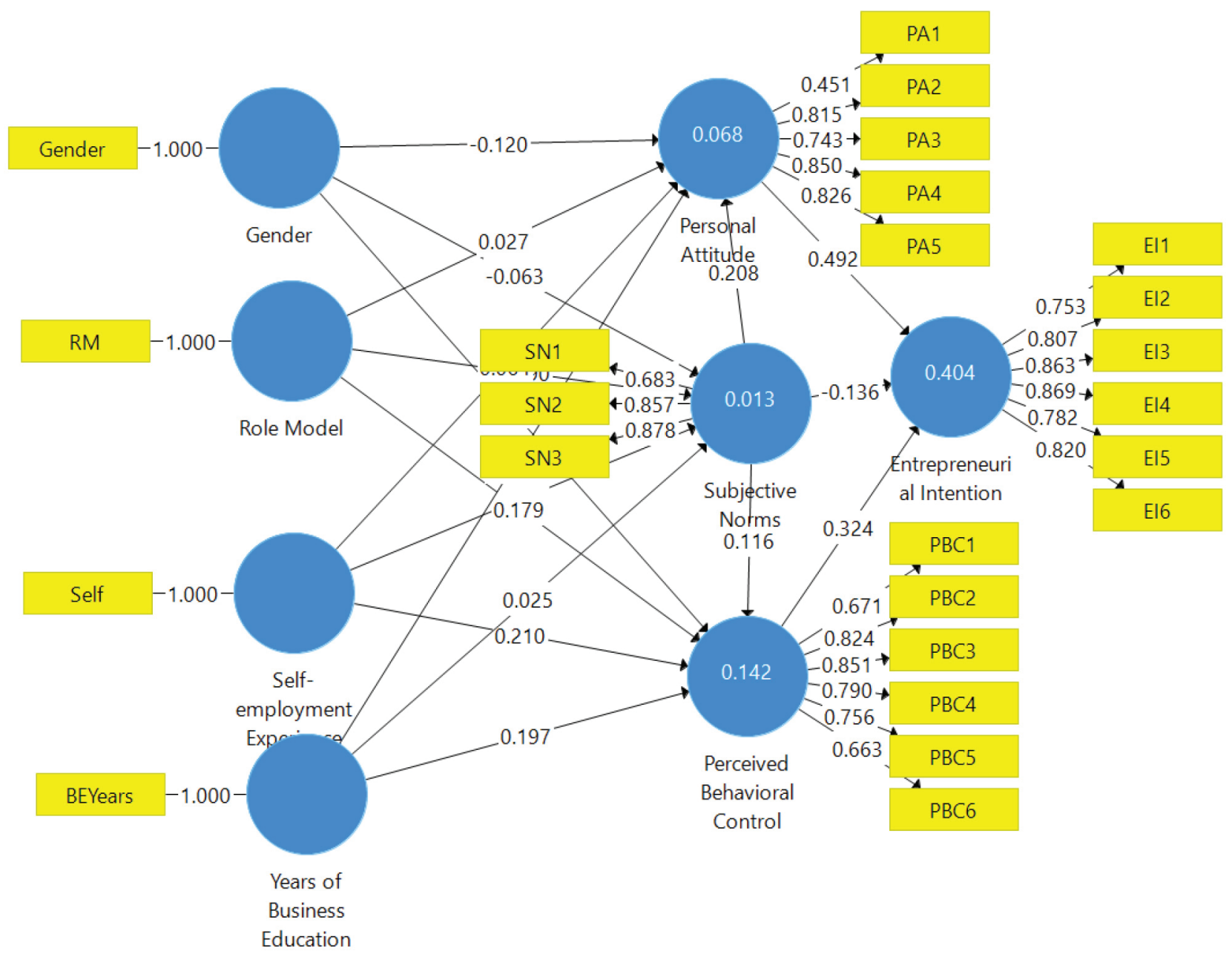

Figure 2: SEM Results

Demographic and human capital variables have not shown much significant effects on the antecedents of EIM, with the exceptions of Gender-PA, SEE-PBC and YBEPBC being significant. Similar findings have been reported earlier (Liñán, 2005). Gender was found to be just affecting PA. Earlier a study conducted at King Saud University in Saudi Arabia presented a different finding regarding gender (Almobaireek, 2012). They found that gender was a strong moderating factor that affected EI. Role model, Selfemployment experience and Number of years of business education were found to be significantly affecting Perceived Behavioral Control and no other antecedents of EI. In a study, positive relationship was found between business courses and entrepreneurship (Yusof, Sandhu, \& Jain, 2007). The positive effect of self-employment experience on SN was reported in other studies (Almobaireek, 2012; Liñán \& Chen, 2006).
The results of this study are quite significant for understanding the dimensions of EI of university students in Saudi Arabia. A correct understanding of the EI of students would help in nurturing them adequately that would eventually make it easy for them to become entrepreneurs. Of course, there are still many factors that may prove to be a barrier for students to take up entrepreneurial roles even though they had high EI. This is an important area of further research.

\section{References}

Ajzen, I. (1991). The theory of planned behavior. Organizational Behavior and Human Decision Processes, 50(2), 179-211. https://doi.org/10.1016/0749-5978(91)90020-T

Al-Jubari, I., Hassan, A., \& Liñán, F. (2019). Entrepreneurial intention among University students in Malaysia: integrating 
self-determination theory and the theory of planned behavior. International Entrepreneurship and Management Journal, 15(4), 1323-1342. https://doi.org/10.1007/s11365-018-0529-0

Ali, T. Ben. (2016). Explaining the intent to start a business among Saudi Arabian university students. International Review of Management and Marketing, 6(2), 345-353.

Aloulou, W. J. (2016). Predicting entrepreneurial intentions of final year Saudi university business students by applying the theory of planned behavior. Journal of Small Business and Enterprise Development, 23(4), 1142-1164. https://doi.org/10.1108/ JSBED-02-2016-0028

Amanamah, R. B., Acheampong, A., \& Owusu, E. K. (2018). An exploratory study of entrepreneurial intention among university students in Ghana. International Journal of Scientific and Technology Research, 7(1), 140-148.

Ambad, S. N. A., \& Damit, D. H. D. A. (2016). Determinants of Entrepreneurial Intention Among Undergraduate Students in Malaysia. Procedia Economics and Finance, 37(16), 108-114. https://doi.org/10.1016/s2212-5671(16)30100-9

Amouri, A., Sidrat, S., Boudabbous, S., \& Boujelbene, Y. (2016). Effects of role models on developing entrepreneurial intention among graduate students in Tunisia. IOSR Journal of Business and Management, 18(7), 73-80. https://doi. org/10.9790/487X-1807037380

Audet, J. (2004). A Longitudinal Study of the Entrepreneurial Intentions of University Students. Academy of Entrepreneurship Journal, 10(1-2), 3-16.

Autio, E., Keeley, R. H., Klofsten, M., \& Ulfstedt, T. (1997). Entrepreneurial intent among students: Testing an intent model in Asia, Scandinavia, and USA. Frontiers of Entrepreneurship Research 1997, 133-147.

Benzing, C., Chu, H. M., \& Kara, O. (2009). Entrepreneurs in Turkey: A factor analysis of motivations, success factors, and problems. Journal of Small Business Management, 47(1), 5891. https://doi.org/10.1111/j.1540-627X.2008.00262.x

Bird, B. (1988). Implementing Entrepreneurial Ideas: The Case for Intention. Academy of Management Review, 13(3), 442-453. https://doi.org/10.5465/amr.1988.4306970

Bosma, N., Acs, Z. J., Autio, E., Coduras, A., \& Levie, J. (2008). 2008 Executive Report Global Entrepreneurship Monitor 2008 Executive Report. Executive Report, 14, 146. Retrieved from http:/www.mendeley.com/research/global-entrepreneurshipmonitor-2004-executive-report/

Boyd, N. G., \& Vozikis, G. S. (1994). The Influence of Self-Efficacy on the Development of Entrepreneurial Intentions and Actions. Entrepreneurship Theory and Practice, 18(4), 63-77. https:// doi.org/10.1177/104225879401800404

Bui, T. H. V., Nguyen, T. L. T., Tran, M. D., \& Nguyen, T. A. T. (2020). Determinants Influencing Entrepreneurial Intention among Undergraduates in Universities of Vietnam. The Journal of Asian Finance, Economics and Business, 7(7), 369-378. https://doi.org/10.13106/jafeb.2020.vol7.no7.369

Choukir, J., Aloulou, W. J., Ayadi, F., \& Mseddi, S. (2019). Influences of role models and gender on Saudi Arabian freshman students' entrepreneurial intention. International Journal of Gender and Entrepreneurship, 11(2), 186-206. https://doi.org/10.1108/ IJGE-08-2018-0083

Concordia, J. A. (2000). Evaluation of Two Approaches to Entrepreneurship Education Using an Intention-Based Model of Venture Creation. Academy of Entrepreneurship Journal, 6(1), 58.

De Pillis, E., \& Reardon, K. K. (2007). The influence of personality traits and persuasive messages on entrepreneurial intention: A cross-cultural comparison. Career Development International, 12(4), 382-396. https://doi.org/10.1108/13620430710756762

do Paço, A. M. F., Ferreira, J. M., Raposo, M., Rodrigues, R. G., \& Dinis, A. (2011). Behaviours and entrepreneurial intention: Empirical findings about secondary students. Journal of International Entrepreneurship, 9(1), 20-38. https://doi. org/10.1007/s10843-010-0071-9

Engle, R. L., Dimitriadi, N., Gavidia, J. V., Schlaegel, C., Delanoe, S., Alvarado, I., ... Wolff, B. (2010). Entrepreneurial intent: A twelve-country evaluation of Ajzen's model of planned behavior. Team Performance Management, 16(1-2), 35-57. https://doi.org/10.1108/13552551011020063

Ferri, L., Ginesti, G., Spanò, R., \& Zampella, A. (2018). Exploring the entrepreneurial intention of female students in Italy. Journal of Open Innovation: Technology, Market, and Complexity, 4(3). https://doi.org/10.3390/joitmc4030027

Fitzsimmons, J. R., \& Douglas, E. J. (2011). Interaction between feasibility and desirability in the formation of entrepreneurial intentions. Journal of Business Venturing, 26(4), 431-440. https://doi.org/10.1016/j.jbusvent.2010.01.001

Garson, G. D. (2016). Partial least squares regression and structural equation models [Kindle edition]. In Statistical Associates Blue Book Series 10. Asheboro, NC 27205 USA: Statistical Associates Publishing, Asheboro.

Granovetter, M. S. (1973). The Strength of Weak Ties. American Journal of Sociology, 78(6), 1360-1380. https://doi. org/10.1086/225469

Gupta, V. K., \& Bhawe, N. M. (2007). The Influence of Proactive Personality and Stereotype Threat on Women's Entrepreneurial Intentions. Journal of Leadership \& Organizational Studies, 13(4), 73-85. https://doi.org/10.1177/10717919070130040901

Hair, J. F., Ringle, C. M., \& Sarstedt, M. (2011). PLS-SEM: Indeed a silver bullet. Journal of Marketing Theory and Practice, 19(2), 139-152. https://doi.org/10.2753/MTP1069-6679190202

Hmieleski, K. M., \& Corbett, A. C. (2006). Proclivity for improvisation as a predictor of entrepreneurial intentions. Journal of Small Business Management, 44(1), 45-63. https:// doi.org/10.1111/j.1540-627X.2006.00153.x

Hongdiyanto, C., Teofilus, T., Sutrisno, T., \& Dewanti, P. S. P. (2020). The Effect of Entrepreneurial Learning towards Entrepreneurial Intention of Indonesian Women. Journal of Asian Finance, Economics and Business, 7(9), 573-582. https://doi.org/https:// doi.org/10.13106/jafeb.2020.vol7.no9.573

Iqbal, A., Melhem, Y., \& Kokash, H. (2012). Readiness of the University Students Towards Entrepreneurship in Saudi Private 
University : an Exploratory Study. Eurpean Scientific Journal, $8(15), 109-131$.

Israr, M., \& Saleem, M. (2018). Entrepreneurial intentions among university students in Italy. Journal of Global Entrepreneurship Research, 8(1). https://doi.org/10.1186/ s40497-018-0107-5

Jahani, S., Babazadeh, M., Haghighi, S., \& Cheraghian, B. (2018). The effect of entrepreneurship education on self-efficacy beliefs and entrepreneurial intention of nurses. Journal of Clinical and Diagnostic Research, 12(6), LC18-LC21. https://doi. org/10.7860/JCDR/2018/31525.11654

Kautonen, T., van Gelderen, M., \& Fink, M. (2015). Robustness of the theory of planned behavior in predicting entrepreneurial intentions and actions. Entrepreneurship: Theory and Practice, 39(3), 655-674. https://doi.org/10.1111/etap.12056

Kolvereid, L., \& Isaksen, E. J. (2012). The Psychology of the Entrepreneur. In Perspectives in Entrepreneurship (pp. 27-39). https://doi.org/10.1007/978-0-230-35809-6 3

Krueger, N. F., Reilly, M. D., \& Carsrud, A. L. (2000). Competing models of entrepreneurial intentions. Journal of Business Venturing, 15(5), 411-432. https://doi.org/10.1016/S08839026(98)00033-0

Lee-Ross, D. (2017). An examination of the entrepreneurial intent of MBA students in Australia using the entrepreneurial intention questionnaire. Journal of Management Development, 36(9), 1180-1190. https://doi.org/10.1108/jmd-10-2016-0200

Lee, S. M., Lim, S. B., Pathak, R. D., Chang, D., \& Li, W. (2006). Influences on students attitudes toward entrepreneurship: A multi-country study. International Entrepreneurship and Management Journal, 2(3), 351-366. https://doi.org/10.1007/ s11365-006-0003-2

Licht, A. N., \& Siegel, J. I. (2009). The Social Dimensions of Entrepreneurship. In The Oxford Handbook of Entrepreneurship. https://doi.org/10.1093/oxfordhb/9780199546992.003.0019

Liñán, F. (2005). Development and Validation of an Entrepreneurial Intention Questionnaire (EIQ). Fostering Entrepreneurship Through Education. Intent Conference (15). Retrieved from http://www.intent-conference.com/structure_default/ePilot40. asp?G $=621 \& A=1$

Liñán, Francisco, \& Chen, Y. (2006). Testing the Entrepreneurial Intention Model on a two-country Sample. Documents de Treball, 06/7(November), 1-37.

Liñán, Francisco, \& Chen, Y. W. (2009). Development and crosscultural application of a specific instrument to measure entrepreneurial intentions. Entrepreneurship: Theory and Practice, 33(3), 593-617. https://doi.org/10.1111/j.15406520.2009.00318.x

Liñán, Francisco, Nabi, G., \& Kueger, N. (2013). British and Spanish entrepreneurial intentions: A comparative study. Revista de Economia Mundial, (33), 73-103.

Liñán, Francisco, Rodríguez-Cohard, J. C., \& Rueda-Cantuche, J. M. (2011a). Factors affecting entrepreneurial intention levels: A role for education. International Entrepreneurship and
Management Journal, 7(2), 195-218. https://doi.org/10.1007/ s11365-010-0154-Z

Liñán, Francisco, Rodríguez-Cohard, J. C., \& Rueda-Cantuche, J. M. (2011b). Factors affecting entrepreneurial intention levels: A role for education. International Entrepreneurship and Management Journal, 7(2), 195-218. https://doi.org/10.1007/ s11365-010-0154-z

Liñán, Francisco, Urbano, D., \& Guerrero, M. (2011). Regional variations in entrepreneurial cognitions: Start-up intentions of university students in Spain. Entrepreneurship and Regional Development, 23(3-4), 187-215. https://doi. org/10.1080/08985620903233929

Lu, H., \& Wang, J. (2018). Entrepreneurial intention of two patterns of planned behaviour and alertness: Empirical evidence in China. Journal of Asian Finance, Economics and Business, 5(2), 63-72. https://doi.org/10.13106/jafeb.2018.vol5.no2.63

Lüthje, C., \& Franke, N. (2003). The "making" of an entrepreneur: Testing a model of entrepreneurial intent among engineering students at MIT. $R$ and D Management, 33(2), 135-147. https:// doi.org/10.1111/1467-9310.00288

Miao, C. (2016). Individual traits and entrepreneurial intentions: The mediating role of entrepreneurial selfefficacy and need for cognition. Dissertation Abstracts International Section A: Humanities and Social Sciences, 76(10-A(E)), No-Specified. Retrieved from http://ovidsp. ovid.com/ovidweb.cgi? $\mathrm{T}=\mathrm{JS} \& \mathrm{PAGE}=$ reference $\& \mathrm{D}=$ psyc13a\&NEWS $=$ N\&AN=2016-16229-280

Miralles, F., Giones, F., \& Riverola, C. (2016). Evaluating the impact of prior experience in entrepreneurial intention. International Entrepreneurship and Management Journal, 12(3), 791-813. https://doi.org/10.1007/s11365-015-0365-4

Mohd Ariff, A. H., Bidin, Z., Sharif, Z., \& Ahmad, A. (2010). Predicting Entrepreneurship Intention Among Malay University Accounting Students in Malaysia. UNITAR E-Journal, 6(1), 1-10. Retrieved from http://search.ebscohost.com/login.aspx?d irect $=$ true $\& \mathrm{db}=\mathrm{a} 9$ h $\& \mathrm{AN}=51444630 \&$ site $=$ ehost-live

Muhammad, A. D., Aliyu, S., \& Ahmed, S. (2015). Entreprenuerial Intention Among Nigerian University Students. American Journal of Business Education (AJBE), 8(4), 239. https://doi. org/10.19030/ajbe.v8i4.9419

Mwiya, B., Wang, Y., Shikaputo, C., Kaulungombe, B., \& Kayekesi, M. (2017). Predicting the Entrepreneurial Intentions of University Students: Applying the Theory of Planned Behaviour in Zambia, Africa. Open Journal of Business and Management, 5(4), 592-610. https://doi.org/10.4236/ojbm.2017.54051

Nabi, G., LiñáN, F., Fayolle, A., Krueger, N., \& Walmsley, A. (2017). The impact of entrepreneurship education in higher education: A systematic review and research agenda. Academy of Management Learning and Education, 16(2), 277-299. https://doi.org/10.5465/amle.2015.0026

Naushad, M. (2018). A study on the antecedents of entrepreneurial intentions among Saudi students. Entrepreneurship and Sustainability Issues, 5(3), 600-617. https://doi.org/10.9770/ jesi.2018.5.3(14) 
Naushad, M., \& Malik, S. A. (2018). The mediating effect of entrepreneurial self-efficacy in entrepreneurial intention - A study in Saudi Arabian context. Problems and Perspectives in Management, 16(1), 267-275. https://doi.org/10.21511/ ppm.16(1).2018.26

Neergaard, H., Shaw, E., \& Carter, S. (2005). The impact of gender, social capital and networks on business ownership: A research agenda. International Journal of Entrepreneurial Behaviour \& Research, 11(5), 338-357. https://doi. org/10.1108/13552550510614999

Nguyen, X. T. (2020). Factors Affecting Entrepreneurial Decision of Nascent Entrepreneurs Belonging Generation Y in Vietnam. The Journal of Asian Finance, Economics and Business, 7(8), 407-417. https://doi.org/10.13106/jafeb.2020.vol7.no8.407

Păunescu, C., Popescu, M. C., \& Duennweber, M. (2018). Factors determining desirability of entrepreneurship in Romania. Sustainability, 10(11). https://doi.org/10.3390/su10113893

Rahman, M. A., Ali, M. J., Mamoon, Z. R., \& Asheq, A. (2020). Understanding the Entrepreneurial Intention in the Light of Contextual Factors: Gender Analysis. Journal of Asian Finance, Economics and Business, 7(9), 639-647. https://doi. org/https://doi.org/10.13106/jafeb.2020.vol7.no9.639

Raposo, M. L. B., Matos Ferreira, J. J., Finisterra Do Paço, A. M., \& Gouveia Rodrigues, R. J. A. (2008). Propensity to firm creation: Empirical research using structural equations. International Entrepreneurship and Management Journal, 4(4), 485-504. https://doi.org/10.1007/s11365-008-0089-9
Sata, M. (2013). Entrepreneurial Intention Among Undergraduate Business Students'. International Journal of Research in Management, Economics and Commerce, 3(9), 33-48.

Soria-Barreto, K., Honores-Marin, G., Gutiérrez-Zepeda, P., \& Gutiérrez-Rodríguez, J. (2017). Prior exposure and educational environment towards entrepreneurial intention. Journal of Technology Management and Innovation, 12(2), 45-58. https:// doi.org/10.4067/S0718-27242017000200006

Tran, A. T., Von Korflesch, H., \& Atp, T. (2018). Social Entrepreneurship Intention: The Case of National Economics University's Students. Advance Research Journal of MultiDisciplinary Discoveries I I Issue - Advance Research Journal of Multidisciplinary Discoveries. Advance Research Journal of Multi-Disciplinary Discoveries I, 232300(23), 27-34.

Vuong, B. N., Phuong, N. N. D., Huan, D. D., \& Quan, T. N. (2020). A Model of Factors Affecting Entrepreneurial Intention among Information Technology Students in Vietnam. The Journal of Asian Finance, Economics and Business, 7(8), 461-472. https://doi.org/10.13106/jafeb.2020.vol7.no8.461

Wafa N. Almobaireek. (2012). Who wants to be an entrepreneur? Entrepreneurial intentions among Saudi university students. African Journal of Business Management, 6(11), 4029-4040. https://doi.org/10.5897/ajbm11.1521

Yusof, M., Sandhu, M., \& Jain, K. (2007). Relationship between psychological characteristics and entrepreneurial inclination: A case study of students at University Tun Abdul Razak (Unitar). Journal of Asia Entrepreneurship and Sustainability, 3(2), 1. 